\title{
Proceeding
}

Supplementary Issue: Summer Conferences of Sports Science. Costa Blanca Sports Science Events, 25-26 September 2020. Alicante, Spain.

\section{Strategy proposal for the redesign of the Subject Program Athletics I of the Physical Education career curriculum approach by competence according to the educational model of the university}

DIGNA AZUCENA AGUILERA ${ }^{1}$, VEANNEY SEBASTIÁN RIVERA-AGUILERA², REIDEL CORDOVÉSPEINADO 1

${ }^{1}$ National Autonomous University of Honduras, Tegucigalpa, Honduras

2Unaffiliated researcher, Tegucigalpa, Honduras

\begin{abstract}
A study was carried out at the micro-curriculum level at the National Autonomous University of Honduras, justified from the problem in the specific training in the subject of athletics I in the Physical Education career. As an objective, a strategy was proposed that favoured the redesign of the program of the Athletics I subject of the Physical Education Career Curriculum, through a competency approach according to the Educational Model of the National Autonomous University of Honduras. The qualitative study was justified from the fact that experts, teachers, coaches and students who are the direct protagonists in the development of the curriculum were considered as key informants, however, coverage is increased by involving employers, graduates, sports authorities in athletics, accompanied by national and international advisers and consultants, in the area of curriculum with a focus on competence in physical education and sport through the application of interviews, surveys to demonstrate both the existing shortcomings and the progress obtained after the application of the strategy; It was possible to modify from the use of competences of the students of the physical education career in the athletics sport with conceptual, procedural and attitudinal knowledge and therefore with a coherent methodology to the new approaches such as: problem-based learning and project methodology, and specific sports skills of the different competitive tests in athletics.

Keywords: Competitions; Curricular redesign; Training by competitions; Athletics.

Cite this article as:

Aguilera, D.A., Rivera-Aguilera, V.S. \& Cordovés-Peinado, R. (2020). Strategy proposal for the redesign of the Subject Program Athletics I of the Physical Education career curriculum approach by competence according to the educational model of the university. Journal of Human Sport and Exercise, 15(4proc), S1394-S1406. doi:https://doi.org/10.14198//hse.2020.15.Proc4.36
\end{abstract}

Corresponding author. National Autonomous University of Honduras, Tegucigalpa, Honduras. https://orcid.org/0000-0002$\underline{0903-8529}$

E-mail: Daza610@yahoo.com

Abstract submitted to: Spring Conferences of Sports Science. Costa Blanca Sports Science Events, 19-20 June 2020. Alicante, Spain.

JOURNAL OF HUMAN SPORT \& EXERCISE ISSN 1988-5202

(C) Faculty of Education. University of Alicante

doi:10.14198/jhse.2020.15.Proc4.36

S1394

| 2020 | Proc4 | VOLUME 15

(C) 2020 University of Alicante 


\section{INTRODUCTION}

The corresponding article arises from the investigative result that attends to a transcendental moment in the National Autonomous University of Honduras (UNAH), in the context of the IV University Reform, with academic reform being one of the central dimensions of the transformation process. presents a pertinent Educational Model with international requirements through which it intends to guide the self-evaluation of study plans and programs for different careers.

In this sense, it is an eminent need of the UNAH, to analyse the study plans and programs, according to the requirements of the new Educational Model, in such a way that there is a critical assessment of the current situation, in order to base the new proposals at the macro and micro curricular level where the Physical Education Career is not left out of this phenomenon and in order to achieve permanent training it is updating its curriculum; In this sense, principles, concepts and pathways are assumed, as well as common requirements such as: the organization of the subject system, the relationships between disciplines, and the generic competences of the university, such as the specific ones that emerge from the nature of the profession in view that the changes that take place in the educational system in higher education, as an expression of an Educational Revolution, demand the formation of a comprehensive professional who must also be updated and contextualized, whose perspective is in accordance with social demands.

As a reference of them for the research, the athletics discipline is chosen, which motivates the researcher to take as a starting point the characteristics such as that it is the sport with the greatest identity in the universities worldwide where the race is studied, given by Being an activity of crowds, it is content of study at all levels of physical education in schools, colleges and universities, taking into account that its essence is in basic motor skills. (walking, running, jumping, throwing), other sports use their peculiarities to help them with their preparations.

However, when one speaks of the in-depth study of athletics with professional intentions, it is not being able to execute the movements to obtain a performance but to acquire skills that allow others to prepare; That is where the figure of the coach must acquire the necessary skills to carry out his work. Therefore, it is necessary to reach the purpose of contributing with a proposal for the development of knowledge at the micro-curriculum level in higher education and within the framework of the new Educational Model, based on a curricular analysis of the EF-Athletics subjects programs in the Physical Education Career, at the same time designing and evaluating a proposal for curricular redesign, using a strategy as a form of contribution, which allows transforming the reality of the conditions in which the subjects are found.

The relevance of the study is beneficial for management in sports activity at UNAH; In fact, there is an infrastructure that allows to sustain technological scientific advancement in current contexts, where athletics stands out as one of the sports that offers leisure opportunities for all age groups in the country.

Therefore, this sport is not disconnected from the formative nature of the Physical Education graduate. It has repercussions from the first year through the Athletics I subject, which is compulsory even though it is taken without requirement; hence the rest of the knowledge is based on elective continuity for the three orientations II and III.

The theoretical bases as a reference for the contribution of the studies of Boned, Mayorga, (2004) Jiménez, Mayorga, Rodríguez, \& Boned, (2006) and Argudin (2010) who confirm the existence of professional profiles, with specific competences for each profile; which are established in Europe from the Declaration of the 
Tuning-Europe Project of Bologna in 1999 and in several Latin American countries such as: Argentina, Mexico and Costa Rica, among others, from the Tuning Latin America Work meetings carried out in Buenos Aires, March 2005, which is ruled out by the overwhelming contextual differences between what is taught in universities and the reality they will face as future professionals, as will the future coach of athletics sports.

It is important to consider that when there is an adequate teaching and training process in sport and that they are part of the coach's behaviours and behaviours, however, many of these future professionals do not have a history as athletes, which could have contributed to the formative development in an effective way, which makes it necessary to know the different characteristics and behavioural, cognitive and social aspects of the coach (Ayala, Aguirre, Ramos, 2014).

Also, that aspects such as creativity are combined in their training, taking into account that a creative practice leads to an effective professional practice, this being one of the most sought-after attributes in coach training. (Filgueiras 2015)

\section{METHOD}

\section{Participants}

The sample chosen intentionally, makes participants teachers and students with the following characteristics:

Teachers of the UNAH of the Career of Physical Education: (20) teachers of the Career of Physical Education of the UNAH (16 men and 4 women), of them (17) are assistants and (3) holders; with scientific category there are (3) master's and (1) doctor of sciences. 100\% show experience teaching sports modalities, however (8) have ventured into athletics therefore they have some knowledge of the current Curriculum and their respective programs.

Table 1. Representation of the teachers of the Physical Education Career that make up the sample.

\begin{tabular}{|c|c|c|c|c|c|c|c|c|c|c|c|c|c|c|}
\hline \multirow{3}{*}{ Teachers } & \multicolumn{4}{|c|}{ Sex } & \multicolumn{4}{|c|}{ Teaching category } & \multicolumn{6}{|c|}{ Athletics subject experience } \\
\hline & \multicolumn{2}{|c|}{$\mathrm{M}$} & \multicolumn{2}{|c|}{$\mathrm{F}$} & \multicolumn{2}{|c|}{ Aux. } & \multicolumn{2}{|c|}{ Tit. } & \multicolumn{2}{|c|}{ Esp. } & \multicolumn{4}{|c|}{ M.Sc } \\
\hline & $\#$ & $\%$ & \# & $\%$ & $\#$ & $\%$ & \# & $\%$ & \# & $\%$ & \# & $\%$ & \# & $\%$ \\
\hline 20 & 16 & 80 & 4 & 20 & 17 & 85 & 3 & 15 & 0 & 0 & 3 & 15 & 8 & 40 \\
\hline
\end{tabular}

Coaches from the Honduran Athletics Federation: (18) coaches who work in the training process in the country. Of which (13) are men and (5) women, (14) of them work with initiation groups in the practice of athletics in schools and universities and (4) in high performance in the stadium of the José Simón Azcona Sports Complex.

Table 2. Representation of the coaches of the Honduran Athletics Federation that make up the sample.

\begin{tabular}{|c|c|c|c|c|c|c|c|c|}
\hline \multirow{3}{*}{ No. coaches } & \multicolumn{4}{|c|}{ Sex } & \multirow{2}{*}{\multicolumn{2}{|c|}{ Initiation }} & \multirow{2}{*}{\multicolumn{2}{|c|}{ High performance }} \\
\hline & \multicolumn{2}{|c|}{$M$} & \multicolumn{2}{|c|}{$F$} & & & & \\
\hline & $\#$ & $\%$ & $\#$ & $\%$ & $\#$ & $\%$ & $\#$ & $\%$ \\
\hline 18 & 13 & 72.22 & 5 & 27.78 & 14 & 77.77 & 4 & 22.23 \\
\hline
\end{tabular}

Students: (29) are those who select the sports specialty athletics orientation, of which (23) receive athletics II, (5) receive III and (1) receive IV. They are in an age range between 21 and 25 years old and are in the 2017-2021 cycle studying in the full-time modality. 
Table 3. Representation of the students of the Physical Education Career that make up the sample.

\begin{tabular}{lcccccc}
\hline \multirow{2}{*}{ Number of students } & \multicolumn{2}{c}{ Athletics I } & \multicolumn{2}{c}{ Athletics II } & \multicolumn{2}{c}{ Athletics III } \\
\cline { 2 - 7 } & $\#$ & $\%$ & $\#$ & $\%$ & $\#$ & $\%$ \\
\hline 29 & 23 & 79.31 & 5 & 17.24 & 1 & 3.45 \\
\hline
\end{tabular}

Interview with teachers with experience in teaching sports, mainly those who have taught athletics to obtain criteria based on the diagnosis regarding the current state of curricular design in the career.

Interview with the coaches of the Honduran Athletics Federation, to obtain criteria related to the knowledge that a coach must have, as well as their professional skills.

Survey: allowed to analyze the characteristics of the students who receive EF-101 Athletics I for the diagnosis of the investigation.

Analysis of documentary sources: favored the evaluation of various documents with relevant information on the subject.

\section{Descriptive statistics}

In order to analyze the quantitative results of the instruments applied to the sample, tabulation and data processing; SPSS was used through the absolute, relative, accumulated and percentage frequencies, which is a statistical computer program widely used in the exact, social and applied sciences. The original name corresponded to the acronym of Statistical Package for the Social Sciences (SPSS), reflecting the orientation to its original market, although this program is also widely used in other fields such as social sciences and marketing. It is one of the best known statistical programs considering its ability to work with large databases and a simple interface for most analyzes. Used to evaluate educational questions.

\section{Procedures}

We worked on the basis of a strategy which presented a structure that started from:

Course objective: Contribute to implement the transformations in the curricular design of the subjects EF-101 Athletics I in the Physical Education Career in the current conditions, so that it allows to establish learning spaces, as well as transform the modes of action of the teachers and the quality of future graduates, from three stages:

\section{Pre-Active Stage}

The pre-active stage aims to prepare the conditions to implement the application of the contributions, and is made up of the following actions:

- Holding workshops to raise awareness of teachers about the need to improve PE-Athletics subjects, and to project it towards training by competence, within the framework of subject groups and department meetings.

- Workshops on socialization of the content system, method and system of procedures, from the focus on competence in PE-Athletics subjects so that teachers and specialists assess the proposal.

Awareness workshops for teachers on the need to improve the dynamics of the coach's didactic training, and to project it towards attention to diversity. 
With the aim of sensitizing the teachers in charge of directing the training of physical education professionals in the career with the need to transform this process, 5 awareness workshops were carried out; These were developed within the framework of the career group meetings.

Aspects covered:

- Importance of the relevant competencies for the professional performance of the coach.

- Student performance in the EF-Athletics subject.

- Student performance in directing the athletics training class.

- Performance of students in controlling the training process in Athletics.

- Direction of the didactic training of the coach.

Workshop on socialization of the content, method and system of procedures with teachers and specialists.

In order to corroborate the scientific-methodological value of the proposed content, method and system of procedures, as well as the applicability, we proceeded to the socialization of these scientific contributions of the research through a workshop with specialists, where 19 professors from the Career carried out in the training of the professional.

Aspects covered:

- Scientific rigor in the definition of professional competencies in the training of the coach.

- Logical consistency and applicability of the content to be applied

- Scientific-practical value of the designed procedure system. Analysis logic that articulates the system of procedures. Instrumental value of students' learning strategies.

\section{Inter-Active stage}

Objective: Establish the updating of the thematic axes taking into account the essential characteristics of athletics, its updating needs and contextualization to the Honduran realities.

Updating of the thematic plan taking into account the essential characteristics of athletics, its contextualization needs to the Honduran realities.

From the curriculum map that establishes the group of subjects, the group of subjects is established, which are in correspondence with the particularities of the athletics sports training process, which ranges from the knowledge of sport as nature from initiation to high performance.

\section{Guiding Elements for the Redesign of the Subjects}

Regarding the treatment of the contents.

The distribution in four quarters of the EF-Athletics I sports-subjects that make up the discipline will develop the professional training process with a theoretical-practical nature and focused on the progression and ordering of the learning contents, as well as on the solution of problems emphasizing on the logical and pedagogical-psychological factors that guarantee coherence in the didactic presentation of the subject and encourage the student who has chosen orientation $C$ in the athletics discipline, to be able to comply at the end of learning in Supervised Professional Practice.

In the treatment of content, an essential aspect to take into account is the rational organization of the class system, which in this discipline requires a logical correlation of theoretical (knowledge) and practical (skills) 
content, taking into account that complexity of the skills in the field of this profession has a mixed character made up of sports motor skills and professional pedagogical skills.

Thematic methodological system for EF-Athletics programs in relation to the competencies of the physical education professional and future coach

\section{EF-Athletics I}

1. Historical evolution of national and international athletics. Characterization of athletics and competitive exercise according to their modalities

2. Concepts, terminology in athletics

3. Methodology of teaching the technical foundations of the races and jumps tests. (Long, Triple, Height, Pole)

4. Methodology of teaching the technical foundations of throwing tests. (Bullet, Hammer, Disc, Javelin)

Figure 1. the contents of the subject EF-Athletics I.

\section{EF-Athletics I}

\section{GENERIC COMPETENCES}

- Capacity for analysis and synthesis

- Ability to apply knowledge in practice and to generate knowledge from reflecting on practice

- Capacity for adapting to new situations

- Ability to organize and plan

- Complex problem solving and conflict management

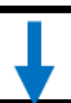

SPECIFIC COMPETENCES

$\square$ Know in a synthetic way the particularities of athletics

$\square$ Explain and demonstrate the specific movements attending to each technique

$\square$ Detect and correct errors in technical movements according to the test

$\square$ Develop exercises to teach the technical elements

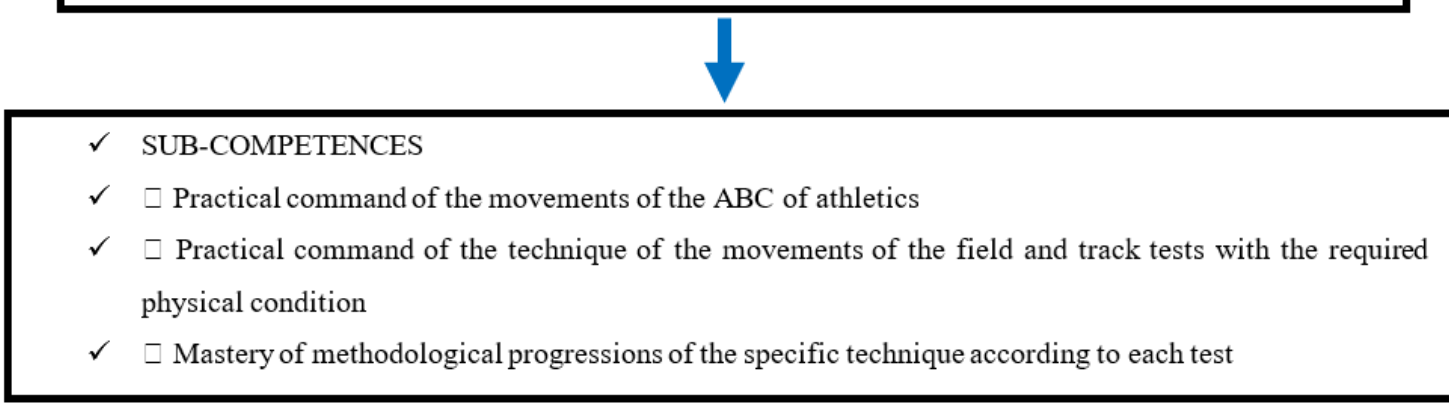

Figure 2. Generic and specific competences. 
As an example of what we can teach in the subject Theory and Methodology of Sports Training we have the improvement of physical condition, the quality of execution of movements, activities that develop reflection and other logical thinking skills aimed at stimulating education and development of intellectual capacities in future professionals.

\section{Regulatory elements of the process object of transformation in the investigation}

Contents and competences: The main requirement of the research contribution is in the proposal of new contents, coming from the nature of the process and from the essential particularities of the athletics sport.

\section{Post-Active stage}

Objective: To evaluate the quality of the structure and content of the curricular elements of the PE-Athletics subject from the classification of Viola Soto Guzmán and from the pedagogical perspective of the Educational Model of the UNAH.

Instructions

Before analysing the content, the observers will master the categorical definitions of the classification of the elements of the curriculum by Viola Soto Guzmán and the definitions of the three pedagogical perspectives of the Educational Model of the UNAH. In order that they can evaluate and describe in the recording instrument what is observed in the EF-101 Athletics I subject program.

Based on the different categorical definitions, the observers will begin the slow reading of the current programs of PE-Athletics subjects, and at the same time they will have the registration instrument at hand, to describe each of the curricular elements present in the Program.

The description of each of the analysis categories will be carried out from an evaluative perspective, describing whether or not they possess the traits that are described in the internalized categorical definitions.

\section{RESULTS}

\section{Interview with Teachers of the Physical Education Career at UNAH}

The result of the interview applied to the teachers to achieve their contribution to the research, two essential aspects were identified: the establishment of professional competences that particularize the graduate of physical education, and the state of the curriculum of the EF-Athletics subject in undergraduate training.

They give an account of knowledge of the competencies that emerge from the Curriculum, which in turn are those of the UNAH educational project, in this sense they do not show knowledge about others that must be characterized and identified by the physical education professional.

Regarding the particularities of the career curriculum, see Curriculum, and subject programs has not received any curricular reform since 1994, in this sense, $100 \%$ of the teachers interviewed have shown compliance with the guidelines and trends towards little variation of the contents in the programs, without taking into account the variations of sports, scientific and technical advances, accounting for a lack of updating.

$80 \%$ state that athletics preparation is based on developing physical skills in the student. Such assertion accounts for the insufficient promotion of pedagogical skills, as well as the disproportion in the theory-practice relationship. 


\section{Athletics Coaches Interview}

$100 \%$ of the interviewees consider that, at the beginning of their work as a coach, they lacked the tools that allowed them to exercise their pedagogical functions.

$90 \%$ consider that the knowledge received at the UNAH in the field of athletics is outdated, taking into account the methods for the preparation of the athlete, the competitive characteristics of the regulations, as well as the tools of a technical scientific nature for the achievement of the functions of direction of the training process.

$100 \%$ of the coaches consider the link between the Honduran Athletics Federation and the UNAH insufficient. In this sense, it is lacking to generate common spaces for the improvement and feedback both of programs for the training of the graduate, as well as the needs of overcoming coaches.

Survey of Students who Receive EF-101 Athletics I. 29 students belonging to the third and fourth year of the career were surveyed, they are chosen intentionally according to the criteria of being in the mention sports and receiving the subjects of EF-Athletics.

In the question that deals with the subject about its assessment of those guiding elements that should be maintained, adapted or changed, the following results were obtained:

Table 4. Representation of students' criteria regarding the guiding elements of the process-

\begin{tabular}{lccc}
\hline Guiding Elements & Stay & Adapt & Change \\
\hline Program Duration & 8 & 14 & 7 \\
Requirements & 18 & 7 & 4 \\
Credits / U.V & 5 & 19 & 5 \\
Theoretical Hours & 4 & 21 & 4 \\
Practical Hours & 3 & 21 & 5 \\
Frequency in the Week & 4 & 12 & 13 \\
Independent Work Hours & 4 & 6 & 19 \\
\hline
\end{tabular}

The element requirements of the subject; It is the one most accepted by the students, where 18 of them consider that it should be maintained, representing $62.06 \%$ of the total, the adaptation criterion in the indicators of the dosage of the relationships between the theoretical and practical hours is also highlighted, as well as credits; Consequently, 72.41 and 62.06 are the most representative indicators in the need for transformation, respectively. In the same way, among the criteria that show disagreement regarding the change, the hours of independent work are valued, being $65.51 \%$ of the total.

The results in the question allow to consider in the research the recognition by the students of the need to adapt and transform the mode of action towards said guiding elements.

It is important that the students concisely state which are those of the generating elements of the process, the presence of the role that they must fulfil is visualized from the following results: 
Table 5. Representation of students' criteria regarding the protagonism of the generating elements of the process.

\begin{tabular}{lcc}
\hline Generator Elements & Yes & No \\
\hline Student Role & 8 & 21 \\
Teacher's role & 23 & 6 \\
Role of the Parent Community & 5 & 24 \\
Socio Cultural Context & 17 & 12 \\
\hline
\end{tabular}

Results of the evaluation of the students regarding the recognition of the competences that they considered they acquired during the period, in this sense dividends of the generic and specific competences are shown, which cover questions 4,5 and 6 of the survey. Consequently, the behaviour of the values that affect the study is described, with generic competences being recognized to a greater extent, but not, with the shortcomings in the specific ones from the quantification of results in the deviation despite being considered in the Plan of Studies of the race. Below are the general tables:

Table 6. Descriptive tabulation results of generic competences perceived by students.

\begin{tabular}{|c|c|c|c|c|c|}
\hline $\begin{array}{l}\text { Communication } \\
\text { skills in a second } \\
\text { language }\end{array}$ & Communication & $\begin{array}{l}\text { Research } \\
\text { capacity }\end{array}$ & $\begin{array}{l}\text { Ability to } \\
\text { learn and } \\
\text { update } \\
\text { constantly }\end{array}$ & $\begin{array}{l}\text { Skills to seek } \\
\text { to process and } \\
\text { analyse } \\
\text { information } \\
\text { from various }\end{array}$ & $\begin{array}{l}\text { Critical } \\
\text { and } \\
\text { self- } \\
\text { critical } \\
\text { ability }\end{array}$ \\
\hline
\end{tabular}

\begin{tabular}{lcccccc}
\hline $\mathrm{N} \quad$ Valid & 29 & 29 & 29 & 29 & 29 & 29 \\
Half & 0 & 0 & 0 & 0 & 0 & 0 \\
Median & 1.34 & 1.34 & 1.17 & 1.28 & 1.28 & 1.34 \\
Standard & 1.00 & 1.00 & 1.00 & 1.00 & 1.00 & 1.00 \\
Deviation & 0.484 & 0.484 & 0.384 & 0.455 & 0.455 & 0.484 \\
Rank & 1 & 1 & 1 & 1 & 1 & 1 \\
Minimum & 1 & 1 & 1 & 1 & 1 & 1 \\
Maximum & 2 & 2 & 2 & 2 & 2 & 2 \\
\hline
\end{tabular}

Table 7. Continuation of descriptive tabulation results of generic competences perceived by students.

\begin{tabular}{|c|c|c|c|c|c|c|}
\hline & $\begin{array}{l}\text { Capacity for } \\
\text { abstraction. } \\
\text { analysis and } \\
\text { synthesis }\end{array}$ & $\begin{array}{l}\text { Ability to } \\
\text { apply } \\
\text { knowledge } \\
\text { in practice }\end{array}$ & $\begin{array}{l}\text { Ability to } \\
\text { organize } \\
\text { and plan } \\
\text { time }\end{array}$ & $\begin{array}{l}\text { Knowledge } \\
\text { about the area } \\
\text { of study and } \\
\text { profession }\end{array}$ & $\begin{array}{l}\text { Social } \\
\text { commitment }\end{array}$ & $\begin{array}{l}\text { Oral and written } \\
\text { communication } \\
\text { skills }\end{array}$ \\
\hline \multirow[t]{2}{*}{$\mathrm{N} \quad$ Valid } & 29 & 29 & 29 & 29 & 29 & 29 \\
\hline & 0 & 0 & 0 & 0 & 0 & 0 \\
\hline Half & 1.55 & 1.28 & 1.34 & 1.28 & 1.31 & 1.31 \\
\hline Median & 2.00 & 1.00 & 1.00 & 1.00 & 1.00 & 1.00 \\
\hline \multirow{2}{*}{\multicolumn{7}{|c|}{ Deviation }} \\
\hline & & & & & & \\
\hline Rank & 1 & 1 & 1 & 1 & 1 & 1 \\
\hline Minimum & 1 & 1 & 1 & 1 & 1 & 1 \\
\hline Maximum & 2 & 2 & 2 & 2 & 2 & 2 \\
\hline
\end{tabular}


Table 8. Descriptive tabulation results of specific competences perceived by students.

\begin{tabular}{|c|c|c|c|c|c|c|}
\hline & $\begin{array}{l}\text { Knows and } \\
\text { applies the } \\
\text { theories on } \\
\text { which general } \\
\text { and specific } \\
\text { didactics are } \\
\text { based on } \\
\text { educational } \\
\text { activities. }\end{array}$ & $\begin{array}{l}\text { Identify and } \\
\text { manage } \\
\text { supports to } \\
\text { meet specific } \\
\text { educational } \\
\text { needs in } \\
\text { different } \\
\text { contexts. }\end{array}$ & $\begin{array}{l}\text { Designs and } \\
\text { implements } \\
\text { various } \\
\text { learning } \\
\text { evaluation } \\
\text { strategies and } \\
\text { processes } \\
\text { based on } \\
\text { determined } \\
\text { criteria. }\end{array}$ & $\begin{array}{l}\text { Designs. } \\
\text { manages. } \\
\text { implements } \\
\text { and evaluates } \\
\text { educational } \\
\text { programs and } \\
\text { projects. }\end{array}$ & $\begin{array}{l}\text { Selects. } \\
\text { develops } \\
\text { and uses } \\
\text { teaching } \\
\text { materials } \\
\text { relevant to } \\
\text { the } \\
\text { context. }\end{array}$ & $\begin{array}{l}\text { Creates and } \\
\text { evaluates } \\
\text { supportive and } \\
\text { challenging } \\
\text { environments } \\
\text { for learning. }\end{array}$ \\
\hline $\mathrm{N} \quad$ Valid & 29 & 29 & 29 & 29 & 29 & 29 \\
\hline Lost & 0 & 0 & 0 & 0 & 0 & 0 \\
\hline Half & & 1.72 & 1.79 & 1.72 & 1.69 & 1.69 \\
\hline Median & & 2.00 & 2.00 & 2.00 & 2.00 & 2.00 \\
\hline $\begin{array}{l}\text { Standard } \\
\text { Deviation }\end{array}$ & & 0.455 & 0.412 & 0.455 & 0.471 & 0.471 \\
\hline Rank & & 1 & 1 & 1 & 1 & 1 \\
\hline Minimum & & 1 & 1 & 1 & 1 & 1 \\
\hline Maximum & & 2 & 2 & 2 & 2 & 2 \\
\hline
\end{tabular}

In the criteria collection questions, considerations were provided such as: regarding the possibilities of applying the knowledge received in teaching in practice, $72 \%$ state that, very scarcely, considering that the coaches use other methods that they do not recognize.

They consider that the study guide received to apply in practice, they state that, despite being consistent with the training space, it is applicable, but at the same time insufficient considering the level of rigor of the training process.

The knowledge considerations received in practice by the advisory coaches, as well as the accumulated experiences, both in training and competitions, suggest that much knowledge associated with general training is established, however, the specifications towards the training are very poor. Athletics.

In this sense, they are in agreement with the dosage of the classes, credits and value units, however, they do not agree with the distribution of the practical and theoretical classes, in the same way with the hours dedicated to independent work.

They consider that the quality of the process as they have received it, values the role of the teacher with an active role, theirs participative, but at the same time with productive, reflective and constructivist deficiencies, according to the survey results. In terms of their responses regarding competencies, they have been able to identify those used in the process through which they have gone.

They are motivated by learning to acquire new knowledge, however, they consider that they have little access to essential sources and limitations in the possibilities of exchange, with personnel with the required competence, although the practice responds to this need, they consider that it can be solved from athletics I and II learning spaces. 
Regarding the recognition of competences by the surveyed students who have received the subject EF-101 Athletics I, it allows the analysis of questions four, five and six to represent from the following graphs the incidence of competencies in students, In this sense it is represented below:

In the question where the students indicate the competences they developed in the period when receiving the subject EF-101 Athletics I, the graph shows a predominance in the recognition of generic competences over specific ones, with high prevalence in the IS.

Table 9. Continuation of descriptive tabulation results of specific competencies perceived by students.

\begin{tabular}{|c|c|c|c|c|c|c|}
\hline & $\begin{array}{l}\text { Develops } \\
\text { logical. } \\
\text { critical and } \\
\text { creative } \\
\text { thinking of } \\
\text { learners }\end{array}$ & $\begin{array}{l}\text { Achieve } \\
\text { learning } \\
\text { outcomes } \\
\text { at different } \\
\text { levels of } \\
\text { knowledge. }\end{array}$ & $\begin{array}{l}\text { Designs } \\
\text { and } \\
\text { implements } \\
\text { educational } \\
\text { actions that } \\
\text { integrate } \\
\text { people with } \\
\text { special } \\
\text { needs. }\end{array}$ & $\begin{array}{l}\text { Select. use and } \\
\text { evaluate } \\
\text { information } \\
\text { and } \\
\text { communication } \\
\text { technologies } \\
\text { as a teaching } \\
\text { and learning } \\
\text { resource. }\end{array}$ & $\begin{array}{l}\text { Educate in } \\
\text { values. in } \\
\text { civic } \\
\text { education } \\
\text { and in } \\
\text { democracy. }\end{array}$ & $\begin{array}{l}\text { Investigates in } \\
\text { education and } \\
\text { applies the } \\
\text { results in the } \\
\text { systematic } \\
\text { transformation } \\
\text { of educational } \\
\text { practices. }\end{array}$ \\
\hline $\mathrm{N}$ Valid & 29 & 29 & 29 & 29 & 29 & 29 \\
\hline Lost & 0 & 0 & 0 & 0 & 0 & 0 \\
\hline Half & 1.79 & 1.76 & 1.62 & 1.79 & 1.72 & 1.66 \\
\hline Median & 2.00 & 2.00 & 2.00 & 2.00 & 2.00 & 2.00 \\
\hline $\begin{array}{l}\text { Standard } \\
\text { Deviation }\end{array}$ & 0.412 & 0.435 & 0.494 & 0.412 & 0.455 & 0.484 \\
\hline Rank & 1 & 1 & 1 & 1 & 1 & 1 \\
\hline Minimum & 1 & 1 & 1 & 1 & 1 & 1 \\
\hline Maximum & 2 & 2 & 2 & 2 & 2 & 2 \\
\hline
\end{tabular}

The question of the survey where the students show the considerations regarding the competences that from their point of view should have been considered or taken into account from a future vision, in this sense it is intended to show in the graph that the generic competences predominate On the specific ones, this being a latent need in the specific processes of the Physical Education Career and in turn in the subject EF-101 Athletics I.

The results established in the survey allow to establish, together with the rest of the results that the agents involved in the process imply, give evidence of the existing deficiencies in social practice, with the recognition of the three instruments applied.

\section{DISCUSSION}

The results in the research, in which three essential protagonists are involved, the drivers of the process, those who live in social reality and those who are the object of learning. Therefore, shortcomings are evident, which limit the quality of the process and the output of a graduate with the necessary skills to face reality as happens in the athletic trainer, these are summarized in the demonstrated lack of updating of the contents considering that the preparation of the student has been based on mastering the movements and not the professional skills, this has transcended through the years since the beginning of the Physical Education career at UNAH due to the limited preparation of the teachers in terms of design curricular, expression of a process with a reproductive nature where there is a lack of bibliographies that are a function of the training 
of the trainer, thus being a process with an imbalance in the theoretical and practical classes with a lack of pedagogical competences of a particular didactics of the theory and sports training methodology, which leads to little approach to reality in practice social considering that the competitions move away from the sports training process from the position of the teacher and not an athlete. By recognizing these characteristics of how the process has behaved, it is recognized the need for it to be perfected under the proposal of a new curriculum for the teaching of Athletics I, taking into account current perspectives such as through professional skills; That is the relevance of this research where the final results can be assessed upon graduation of the bachelor's degree in Physical Education, in this case the specialty of Athletics.

\section{CONCLUSIONS}

The study of the PE-Athletics subject showed the insufficient treatment of both Generic and Specific competences, which supports the need for a redesign that addresses this aspect from its didactic treatment. As part of the practical construction provided, the design of the strategy allows the contextualization and transformation of the curriculum in the subject EF-101 Athletics I, which is an expression of the relationships in each of the stages with their actions, which constitute the aspect dynamizer, and the knowledge system is deployed in the subjects and the link with the generic and specific professional competencies of the future graduate.

\section{REFERENCES}

Angulo, J. F. and Blanco, N. (1994) Curriculum Theory and Development. Aljibe, Malaga.

Araujo, B. (2009) Planning and learning cycle. Quito. Santillana Editorial.

Argudin, Y. (2010) Competence-based education. Available at: https://mcyte.wordpress.com/

Ayala, C.F, Aguirre, H; Ramos, S. (2014) Academic training and sports experience of South American coaches. Brazilian Magazine of Science do Esporte.

Bolaños, G and Molina, G. (2004) Introduction to the curriculum. Editorial State Distance University. San Jose Costa Rica.

Boned, G. Mayorga, A. (2004) Professional competences of the graduate in science of physical activity and sport.

Casanova, M. A. (2006). Curricular design and educational innovation. Editorial La Muralla.

Casanova, M. A. (2011). Evaluation for educational inclusion. RIEE. Ibero-American Journal of Educational Evaluation.

Casanova, M. A. (2012). Curriculum design as a factor of educational quality reice. Ibero-American Journal on Quality, Efficacy and Change in Education, 10 (4) Ibero-American Research Network on School Change and Efficacy Madrid, Spain.

Díaz, Á. (2003). Curriculum: conceptual and practical tensions. Electronic journal of educational research, 5 (2).

Filgueira, M. (2015) Multifaceted profile of the high performance coach in athletics. Doctoral Thesis, Faculty of Education. Uned.

Gómez, A. Sosa, G. (2008) New curricular proposal for the area of Physical Education in Primary Education. International Journal of Medicine and Sciences of Physical Activity and Sport vol. 8 (29).

Hernández, R. \& Fernández, C. (2010). Investigation methodology. McGraw-Hill Interamericana Editores, $\mathrm{SA}$.

International Association of Athletics Federations (2015) Competition regulations. Available at: http://www.iaaf.org 
Jiménez, A.M, Mayorga, J.l; Rodríguez, G., \& Boned, C.J (2006) Professional competences of the graduate in physical activity and sport. European University of Madrid.

Lasso, M. (2010) The pedagogical model for Curriculum Updating and Strengthening of Basic General Education in 2010. Quito. Norma Editorial Group.

López, I. (2001). Content of the study plans of the Bachelor of Science in Physical Activity and Sports in Spain. Apunts. (65).

Moreno, M. (2004). Coach. Practical manual for its development. Barcelona: INDE.

Tardif, J. (2008) Development of a program by competences: From the intention to its implementation "Magazine of curriculum and teacher training, Faculty of Education. Sherbrooke University of Quebec (Canada). Vol. 12, (3). 